\title{
Fen Bilimleri Dersine STEM Entegrasyonu Etkinliklerinin 5. Sınıf Öğrencilerinin Bilimsel Yaratıcılıklarına Etkisi ${ }^{\star}$
}

\section{The Effect of STEM Integration Activities on Scientific Creativities of $5^{\text {th }}$ Grade Students}

\author{
Filiz GÜLHAN ${ }^{* *}$ \\ Fatma ŞAHIN ${ }^{* * *}$
}

\begin{abstract}
Öz. Son yıllarda eğitim dünyasında önemi artan STEM eğitiminin, sınıfta nasıl uygulanabileceği ve öğrenciler üzerindeki potansiyel etkileri önemli birer araştırma konusu olmuştur. Bu araştırmanın problemi "Fen Bilimleri dersine STEM entegrasyonu etkinliklerinin ortaokul beşinci sınıf öğrencilerinin bilimsel yaratıclıklarına etkisi nasıldır?" olarak belirlenmiştir. Durum çalışmasının kullanıldığı araştırma, 2014-2015 eğitim-öğretim yılında İstanbul'daki bir ortaokulda uygulanmıştır. Üç üniteye yönelik altı STEM etkinliğinin on iki hafta süresince uygulandığı araştırmada etkinlikler, araştırmacılar tarafından tasarlanmıştır. Öğrenciler heterojen yapıdaki işbirlikli takımlarla, problemlere çözüm olabilecek tasarımlar yapmışlardır. Araştırmada kullanılan veri toplama araçları; "bilimsel yaratıcılık soruları", "öğrenci günlükleri", "tasarım kâğıtları", "fotoğraflar ve sunum videoları"dır. Bu dokümanlar "bilimsel yaratııılık rubriği" ve "ürün değerlendirme rubriği" ile analiz edilmiştir. Araştırmada STEM etkinliklerinin; öğrencilerin bilimsel yaratıcılıklarına sınırlı düzeyde etkisinin olduğu, katmanlara göre değerlendirildiğinde ise en üst yaratııllık düzeyi olan "yansıtıcı düşünme katmanı"nın gelişiminde daha etkili olduğu sonucuna varılmıştır.
\end{abstract}

Anahtar Kelimeler: STEM, etkinlik, ortaokul, bilimsel yaratıcılık.

\begin{abstract}
The STEM education how it can be applied in the class and the potential impacts on the students has been an important research topics. The problem of this research is "How STEM integration activities in science effect the scientific creativity of fifth grade students?" The case study was used in the research. The research was applied in a secondary school in Istanbul in 20142015 academic year. Six STEM activities for three units were performed for twelve weeks. That data collection tools were used in research; "scientific creativity questions", "student diaries", "design papers", "photographs and presentation videos". These documents have been analyzed by "scientific creativity rubric" and "product evaluation rubric". In this research has been found that of the effect of STEM activities on students' scientific creativity was limited in terms of individual development and that in the "reflective thinking layer" which was the highest level of creativity, it was more effective.
\end{abstract}

Keywords: STEM, activity, secondary school, scientific creativity.

\section{Toplumsal Mesaj. \\ STEM eğitimi; fen, teknoloji, mühendislik, matematik alanlarının bir araya getirilerek öğretilmesine dayanan bir yaklaşımdır. Öğrencilerin 21. yüzyıl becerilerinin geliştirilmesi için STEM eğitiminin kritik öneme sahip olduğu düşünülmektedir.}

\section{Public Interest Statement.}

STEM education; science, technology, engineering, math it is an approach based on teaching together. It is thought that STEM education is critical importance for the development of $21^{\text {st }}$ century skills of students.

\footnotetext{
* Bu araştırma birinci yazarın ikinci yazar danışmanlığında 2016 yılında tamamladığı doktora tezinin bir kısmından oluşturulmuştur. Bu araştırma Marmara Üniversitesi tarafından 11-12 Mayıs 2018 tarihinde İstanbul'da düzenlenen 1. Uluslararası Eğitimde Yeni Arayışlar Kongresi'nde (UEYAK-2018) sözlü bildiri olarak sunulmuştur.

** Orcid ID: http://orcid.org/0000-0002-7915-6299, Dr., MEB Mustafa Kemal Ortaokulu, filizgulhan@outlook.com

*** Orcid ID: http://orcid.org/0000-0002-6291-0013, Prof. Dr., Marmara Üniversitesi Atatürk Eğitim Fakültesi Fen Bilgisi Eğitimi Bölümü, fsahin@marmara.edu.tr
} 


\section{GíRiş}

STEM eğitimi; fen, teknoloji, mühendislik, matematik alanlarına yönelik bilgi ve becerilerin bir araya getirilerek öğretilmesine dayanan bir yaklaşımdır. Öğrencilerin bulundukları zamana uyum sağlamaları ve geleceğe hazırlanabilmeleri için, STEM eğitiminin kritik öneme sahip olduğu düşünülmektedir. Özellikle yaratııılık, 21. yüzyılda yaşayan bir birey için kritik unsurlardan biridir. Bu nedenle STEM eğitimi ile yaratıcılığın ilişkilendirilmesi ve öğrencilerin yaratıcılık düzeylerinin geliştirilmesi önem arz etmektedir.

Yaratııılık, problem çözmenin gerektiği farklı bilgi alanlarında kullanılmaktadır (Çellek, 2002; Karakuş, 2001; Yatt ve McCade, 2011). Çellek (2002) yaratıcılığı; "eleştirel biçimde ele alınan problemi alışılmadık, özgün bir yolla çözerek dünyayı ve kendimizi değiştirme eylemi" olarak tanımlamaktadır. Yaratıcı bireyler; esnek, fikirlerin bağlantılarını kurabilen, alışıımışın dışında, estetik zevklere sahip, meraklı, soru soran, benzerlik ve farklılıkları gören, bir şeyler gerçekleştirmenin yollarını sorgulayan bireylerdir (Fisher, 2004). Yaratııılık potansiyeli, bütün çocuklarda var olmakla birlikte tüm zekâ alanlarında ortaya çıkarılmaya ve geliştirilmeye intiyaç duyar (NACCCE, 1999; Robinson ve Koshy, 2004). Bundan dolayı yaratıcılık sadece doğuştan gelmez, eğitimle de geliştirilebilir (Karakuş, 2001). Yatt ve McCade (2011) yaratıcılığı, geliştirilip güçlendirilebilen bir kasa benzeterek açıklamışlardır. Bu nedenle eğitimde yaratıcılığa önem verilmeli ve öğrencilerin doğuştan gelen potansiyelleri köreltilmemeli, geliştirilmelidir.

Yaratıcılık denildiğinde yakın ilişkili olduğu yenilikçilik (inovasyon) da akla gelmektedir. Yaratıcııık ve yenilikçilik; disiplinler arası yaklaşımlarla çeşitli alanlara uyarlanabilen, geniş ve karmaşık kavramlardır (Ferrari, Cachia ve Punie, 2009). Inovasyon; bilim ve teknolojinin kullanılmasıyla, ekonomik ve toplumsal yarar sağlayacak sonuçlar üretmektir (Yamaç, 2001). 21. yüzyıl bilgi toplumunda eğitim, ekonomide etkili olan yaratıcı ve yenilikçi becerilerin teşvik merkezi olarak nitelendirilmektedir (Ferrari ve diğerleri, 2009; Roberts, 2012).

\subsection{Bilimsel Yaratıcılık}

Bilimsel yaratıcılık, belirli bir amaç doğrultusunda bilgiyi kullanarak özgün bir ürün üretme potansiyeli sağlayan bir entelektüel özelliktir (Hu ve Adey, 2002). Bilimsel yaratıcılık, genel yaratıcılıktan bazı farklarla ayrılmaktadır. Bunlardan biri bilimsel yaratıcılığın daha çok bir problemle karşılaşıldığı zaman kullanılmasıdır (Aktamış ve Ergin, 2006). Bilimsel yaratıcıık; problemin fark edilmesi, probleme çözüm bulunması ve özgün bir ürünün ortaya konmasını içerir (Baysal, Kaya ve Üçüncü, 2013). Bilimsel deney, problem çözme, bilim etkinlikleri gibi bilimsel bilgi ve becerilere dayanır (Hu ve Adey, 2002). Öğrencilerin yaratıcılıklarının geliştirilmesi için önce küçük görevlerle bilgi-beceriler öğretilmeli, sonra büyük görevlere geçilmelidir (Barlex, 2007). Öğretimde kullanılan beyin fırtınası, sol beyin (mantıksal) ile sağ beyin (sezgisel) arasındaki bağlantının kurulmasıyla ilham sağlar (Yatt ve McCade, 2011). Yaratıcılık mikro ve makro düzeyde (teşhis, biçimlendirici ve düzey belirleyici) değerlendirilmelidir (Ferrari ve diğerleri, 2009). Fen eğitiminde yaratıcılık gelişiminin değerlendirilmesi için yarı açık uçlu veya açı uçlu etkinlikler yapılmalıdır (Aktamış ve Ergin, 2006).

\subsection{STEM Eğitiminin Bilimsel Yaratıcılıkla illişkilendirilmesi}

K-12 eğitim düzeyinde önemli bir yenilik olan mühendislik; fen, matematik, teknoloji disiplinleriyle bir araya getirilerek STEM eğitimi yaklaşımı oluşturulmuştur. Gomez ve Albrecht (2014), STEM eğitimini "gerçek dünya ile ilgili öğrenme deneyimi kazandırmak için geliştirilen sistematik ve disiplinlerarası bir uygulama" olarak tanımlamaktadır. Reeve (2015)'e göre öğrenciler STEM eğitimiyle "STEM düşünürleri" olarak STEM alanlarını daha iyi anlayarak büyük resmi görmeye başlayabilirler. K-12 düzeyindeki mühendislik eğitimi; öğrencilerin bilimsel yaratıcılık ve problem çözmeleri üzerinde olumlu etkilere sahiptir (Samuels ve Seymour, 2015). Nitekim yaratıcı düşünce, mühendislik tasarım sürecinin gömülü bir parçasıdır (Court, 1998). STEM eğitimi de öğrencilerin doğal meraklarını teşvik eder ve yaratıcı problem çözme tekniklerini benimsemelerini sağlar (Charyton, 2015; Havice, 2015; Roberts, 2012; Samuels ve Seymour, 2015). Larkin (2015) yaratıcI 
STEM projeleri gerçekleştirdiği araştırmasında; öğrencilerin yüksek düzeyde performans gösterdiklerini, "kutunun dışında düşünmek (think outside the box)" deyimini hayata geçirdiklerini, etkinliklerden zevk aldıklarını ve birçok şey öğrendiklerini belirtmiştir. STEM eğitimi öğrencilerin yenilikçi düşünmelerini sağlayarak onları bir sonraki nesle hazırlar (Barcelona, 2014; Cantrell, Pekcan, Itani ve Velasquez-Bryant, 2006; Daugherty, 2009; Driggs Lark, 2015; Havice, 2015; Roberts, 2012).

\subsection{Problem ve Amaç}

STEM disiplinlerini inovasyon düzeyine çıkaran, yaratııllıktır (Hughes, 2017). Özellikle STEM alanlarında yaratıcı ve yenilikçi düşünen bireylere ihtiyaç vardır (Charyton, 2015; Larkin, 2015). Katanski (2013) ABD'de son yirmi yılda STEM alanlarındaki bireylerin yaratıcılığının gittikçe azaldığını ve yaratıcılık ile STEM krizi arasında köprü kurularak ekonomik geleceğin daha iyi olabileceği önerisinde bulunmuştur. Driggs Lark (2015) yaptığı anket çalışmasında ortaokul öğrencilerinin yenilikçilik becerileri ile STEM içeriklerine ve STEM kariyer alanlarına ilgileri arasında anlamlı ilişkiler bulunduğunu tespit etmiştir. Buna karşılık Valenti, Masnick, Cox, Osman (2016) lise ve üniversite öğrencilerinin bilimi yaratıcılık gerektiren bir kariyer alanı olarak görmedikleri sonucuna ulaşmışlardır. Bu nedenle öğrencilerin STEM eğitimiyle elde ettikleri kazanımların gerek bilişsel gerekse kariyer gelişimleri için olumlu etkiye sahip olabileceği yorumu yapılabilmektedir.

STEM eğitiminin bilimsel yaratıcılık üzerine etkisini inceleyen deneysel araştırmalar alanyazında oldukça az sayıdadır (Ceylan, 2014; Kim, Ko, Han ve Hong, 2014; Lee ve Lee, 2013; Suescun-Florez, Cain, Kapila ve Iskander, 2013). STEM eğitiminin bilimsel yaratıcılık üzerine etkisinin incelenmesi amacıyla oluşturulan araştırmanın problemi, "Fen bilimleri dersine STEM entegrasyonu etkinliklerinin 5. sınıf öğrencilerinin bilimsel yaratıcılıklarına etkisi nasıldır?" olarak belirlenmiştir. Araştırmanın; bilimsel yaratııılık ile STEM eğitiminin ilişkilendirilmesi ve böylece araştırmacılaruygulayıcılar için STEM eğitiminin etkileri hakkında bir örnek teşkil etmesi bakımından önem arz ettiği düşünülmektedir.

\section{YÖNTEM}

Araştırmada nitel araştırma yaklaşımlarından biri olan durum çalışması (örnek olay incelemesi) kullanılmıştır. Araştırmada öğrencilerden süreç boyunca nitel yapıda olan dokümanlar toplanmış, dokümanlar arasında bağlantılar kurularak derinlemesine incelemeler yapılmıştır. Durum çalışmalarında genellikle birden fazla veri toplama aracı kullanılarak zengin ve teyit edilebilir verilere ulaşılır ve bu durum yapı geçerliğini arttııı (Çepni, 2010; Yıldırım ve Şimşek, 2008). Bu araştırmada veri toplama aracı olarak çeşitli dokümanlardan yararlanılmıştır.

\section{1 Çalışma Grubu}

Araştırma 2014-2015 eğitim-öğretim yılında istanbul'daki bir ortaokulda uygulanmıştır. Araştırmanın uygulaması kolay ulaşılabilir durum örneklemesi ile seçilen 28 öğrenciden oluşan bir 5. sınıfta gerçekleştirilmiştir. Etkinlikler ve veri toplama araçları tüm sınıfa uygulanmış olsa da çalışma grubu içerisindeki altı işbirlikli takımdan seçilen birer öğrencinin (toplamda altı öğrencinin) verileri değerlendirmeye alınmıştır. Doküman incelemesi araştırmalarında tüm doküman verilerinin incelenmesi mümkün olmayabilir, araştırmacı bir örnekleme yöntemi ile bir grup dokümanı seçebilir (Yıldırım ve şimşek, 2008). Bu öğrencilerin seçiminde ise maksimum çeşitlilik örneklemesi kullanılmıştır. Bu örnekleme türünde amaç genelleme yapmak değil, çeşitli durumlar arasında ortak olan unsurların olup olmadığını bulmak ve problemin farklı boyutlarını ortaya çıkarmaktır (Yıldırım ve Şimşek, 2008). Bu nedenle öğrenciler başarı ve cinsiyet durumlarına göre heterojen bir grup oluşturacak şekilde seçilmişlerdir. Öğrencilerin seçiminde birinci kriter olarak dokümanlarının tam olması ve el yazısının nispeten okunaklı olmasına dikkat edilmiştir. Bu kriteri sağlayan öğrenciler bu kez de birinci dönemdeki Fen Bilimleri dersi notlarına göre sıralama kriterine tâbi tutulmuşlardır. Gruplardan notu 5, 4 ve 3 olan ikişer öğrenci alınmış ve öğrenciler Ö1, Ö2 vb. şekilde kodlanmıştır. 


\subsection{Veri Toplama Yöntemi}

Araştırmada kullanılan veri toplama yöntemi dokümanların analizi ile ortaya çıkarılmıştır. Doküman analizi yazılı ve görsel malzemelerin toplanarak incelenmesini içerir (Sönmez ve Alacapınar, 2011). Kişisel günlükler, açık uçlu sorulara verilen yazılı cevapların incelenmesi de doküman analizi kapsamındadır (Patton, 2014). Araştırmada kullanılan veri toplama araçları, öğrencilerden süreç boyunca elde edilen dokümanlardır.

\subsubsection{Veri Toplama Araçları}

Bu kısımda öğrencilerden süreç boyunca toplanan dokümanların özellikleri açıklanmıştır.

\subsubsection{Bilimsel Yaratıcılık Soruları}

"Bilimsel Yaratıcılık Soruları", veri analiz aracı olan ve verilerin analizi kısmında açıklanan "Bilimsel Yaratıcılık Rubriği"nin öğrencilerin cevaplayacağı biçimde soru formuna dönüştürülmüş hâlidir. "Bilimsel Yaratıcılık Soruları", "Bilimsel Yaratıcılık Rubriği”ndeki basamaklara ve karşıladığı becerilere uygun olarak her etkinlik için ayrı tasarlanan açık uçlu sorulardan oluşmuştur. Altı etkinlik için hazırlanan altı soru formu, tüm gruplar sunumlarını yaptıktan sonra öğrencilere bir ders saati süre verilerek uygulanmıştır. Öğrencilerin yaptıkları tasarımlarla ilgili bilgi ve düşüncelerini yazmaları istenmiştir. Araştırmadaki final etkinliği için tasarlanan Bilimsel Yaratıcılık Soruları Ek-2'de sunulmuştur.

\subsubsection{2 Öğrenci Günlükleri}

Öğrenciler "Bilimsel Yaratıcılık Soruları" için verilen zamanda yeteri şekilde yazmakta ve kendilerini ifade etmekte zorlandıklarından, veri kaybı olmaması için günlük tutmaları istenmiştir. Fen bilimleri dersi işlendikten sonra o gün içerisinde neler yaptıklarını, neler düşündüklerini günlüklerine yazarak düşüncelerini yansıtmışlardır. Böylece zaman kısıtlaması olmadan süreçte neler yaptıklarını detaylı olarak açıklayabildikleri bir alan sağlanmıştır. Dokümanlar incelenirken günlükte yer alan ifadeler, hangi bilimsel yaratıcılık basamağını karşıııyorsa araştırmacılar tarafından o bölüme eklenmiştir. Örneğin; öğrencilerin o gün yaptıkları tasarım aşamalarını anlattıkları bölümler rubriğin strateji katmanına, eleştirel olarak yorumlama yaptıkları bölümler yansıtma katmanına alınarak değerlendirilmiştir. Verileri incelenen bir öğrencinin günlükteki yazıları Ek-3'te verilmiştir.

\subsubsection{Tasarım Kâğıtları}

Tasarım kâğıtlarının içeriği, öğrencilerin çözüme (tasarıma) yönelik bireysel düşünceleridir. Dersin başlangıcında öğrencilere, STEM problem senaryoları sunulmuştur ve gruplarılya bir araya gelmeden bireysel olarak tasarım kâğıtları hazırlamışlardır. Bu kısımda şu soruları yanıtlamışlardır:

- Çözümle ilgili aklınıza gelen tüm fikirleri maddeler halinde yazın.

- En iyi fikri seçin.

- Hayalinizdeki tasarımı çizin.

Bu araçtan elde edilen verilerden Bilimsel Yaratıcılık Rubriği'nin "Hayalinize ulaşabildiniz mi?" sorusunda yararlanılmıştır. Buradaki amaç öğrencinin tasarımı yapmadan, probleme bulduğu ilk çözümle son çözüm arasındaki farkın ortaya çıkarılmasıdır. Verileri incelenen bir öğrencinin tasarım kâğıdına ait fotoğraf Ek-4'te verilmiştir.

\subsubsection{Fotoğraflar ve Sunum Videoları}

Öğrenciler tasarımlarını gerçekleştirirken birinci araştırmacı (öğretmen), aşamaları cep telefonu kamerası ile fotoğraflamıştır. Ayrıca tasarımlar bittikten sonra öğrencilerin tüm sınıfa yaptıkları sunumlar da videoya alınmıştır. Öğrenciler yaklaşık bir dakikalık sunumlarında tasarımlarını tanıtarak çalışma şeklini göstermişler ve maliyetlerini belirtmişlerdir. Araştırmacı fotoğraf ve videolarda öğrencilerin kişisel gizlilikleri açısından yüzlerinin görünmemesine, yalnızca ürettikleri ürünün yansıtılmasına dikkat etmiştir. Tasarımlara ait örnek fotoğraflar Ek-1'de sunulmuştur. 


\subsection{Araştırmanın Uygulanması}

Araştırmada kullanılan fen-teknoloji-mühendislik-matematik alanlarını içeren STEM etkinlikleri, araştırmacılar tarafından geliştirilmiştir. Etkinlikler 5. sınıf 2. dönemdeki üç üniteyi kapsamaktadır. Araştırmanın uygulama aşaması yaklaşık bir dönem olarak 12 hafta sürmüştür. Final projesiyle beraber toplamda 6 adet STEM etkinliği gerçekleştirilmiştir. Etkinlikler; Avizemizi Tasarlayalım, Gölge Materyali Yapalım, Bitki Düzenlemesi Yapalım, Gıda Mühendisi Oluyoruz, Evimizi Tasarlayalım, Ekolojik Yaşam Kenti Projesi adlı 6 etkinliktir. "Avizemizi Tasarlayalım" etkinliğinde optik mühendisi ve endüstri mühendisi gibi düşünerek saydam veya yarı saydam malzemeler kullanılarak, ışın çizimi ve alan hesaplamaları yapılarak avize tasarımı gerçekleştirilmiştir. "Gölge Materyali Yapalım" etkinliğinde optik mühendisi ve endüstri mühendisi gibi düşünerek gölgeyi etkileyen faktörleri belirten material tasarımı gerçekleştirilmiştir. "Bitki Düzenlemesi Yapalım" etkinliğinde peyzaj mimarı ve bitki bilimci gibi düşünerek, bitki yetiştirme ve sulama düzeneği tasarımı gerçekleştirilmiştir. "Gıda Mühendisi Oluyoruz" etkinliğinde gıda mühendisi gibi düşünerek, besinlerin hangi koşullarda saklanması gerektiğiyle ilgili bir deney ve mini buzdolabı modeli tasarımı gerçekleştirilmiştir. "Evimizi Tasarlayalım" etkinliğinde inşaat mühendisi, elektrik mühendisi ve akustik mühendisi gibi düşünerek elektrik düzeneği olan bir ev maketi tasarımı gerçekleştirilmiştir. "Ekolojik Yaşam Kenti" etkinliğinde yapılan tasarımlar biraraya getirilerek, çevre mühendisi ve şehir planlamacısı gibi düşünerek canlıların etkileşim içerisinde yaşadığı bir şehir maketi tasarımı gerçekleştirilmiştir.

Etkinliklerin uygulamasında EiE (Engineering is Elementary) tarafından geliştirilen mühendislik tasarım süreci basamakları (sor, hayal et, planla, yarat, geliştir) kullanılmıştır (Cunningham ve Hester, 2007). Öğrenciler; araştırmacı öğretmen tarafından sunulan problem senaryosunda belirtilen probleme ve koşullara göre çözüm yolları bulmaya çalışmış, takım arkadaşlarıyla beraber en iyi çözümü seçmiş, tasarımlarının çizimini yapmış, malzeme ve planlarını belirlemişlerdir. Temin ettikleri malzemeleri bir araya getirerek tasarımlarını oluşturmuş, tasarımlarını test ederek daha iyi hale getirmeye çalışmışlardır. Grup arkadaşlarıyla beraber tasarımlarının sunumunu yaparak süreci tamamlamışlardır. Aynı basamaklar altı etkinlik için de gerçekleştirilerek süreç boyunca araştırmacı tarafından dokümanlar toplanmıştır.

Etkinlik sürecine örnek olarak ikinci etkinliğin açıklaması şöyle yapılabilir: “Gölge Materyali Yapalım” etkinliğinde ulaşılması beklenen sonuç; gölge oluşumunu gösteren hareketli bir materyal tasarımı yapılmasıdır. Etkinliğin fen bilimleri dersine yönelik amaçları; opak cisimlerle tam gölge oluşumu ve gölgeyi etkileyen değişkenlerin belirlenmesidir. Etkinliğin matematik dersi kazanımları ise ışınların çizimi, geometrik cisimlerle oluşturulan tam gölge şekillerinin belirlenmesidir. Etkinliğin teknoloji açısından amacı; malzeme seçimi, malzemelerin maliyeti ve kullanışlılığıdır. Etkinliğin mühendislik kazanımları; mühendislik tasarım sürecini kullanarak tam gölge konusu için bir optik mühendisi gibi düşünmeleri, malzeme seçimi içinse bir endüstri mühendisi gibi düşünmeleridir. Tüm tasarımların birleştirilmesiyle oluşan final etkinliğinin problem senaryosu, tasarım koşulları, STEM boyutları ve öğrencilerin tasarımlarından örnek fotoğraflar Ek-1'de sunulmuştur.

\subsection{Verilerin Analizi}

Dokümanlar için içerik analizi kullanılmıştır (Yıldırım ve Şimşek, 2008). Çalışma grubu kısmında belirtildiği gibi seçilen altı öğrencinin dokümanları incelenmiştir.

\subsubsection{Bilimsel Yaratıcılıkla ilgili Analiz Araçları}

Bilimsel yaratıcılıkla ilgili veri toplama araçlarından elde edilen veriler "Bilimsel Yaratııılık Rubriği" ve "Tasarım Değerlendirme Rubriği" adlı iki analiz aracı ile incelenmiştir.

Analizler yapılmadan önce dokümanlar araştırmacılar tarafından bilgisayar ortamına aktarılmıştır. Bunun için öğrencilerin etkinliğe yönelik bilimsel yaratıcılık sorularına yazılı olarak verdikleri cevaplar yazılmış, uzmanların tasarımı incelemesi için sunum videoları ve fotoğraflar eklenmiştir. Ayrıca öğrencilerin günlükleri incelenerek bilimsel yaratıcılık katmanlarıyla ilgili veri içeren cümleleri cevaplarına eklenmiş, tasarım kâğıtları da incelenerek tasarımın kâğıt üzerinde planlanmış hali ile 
oluşturulmuş son halinin karşılaştırılması amacıyla ilgili bilimsel yaratıcılık sorusunun cevabı olacak biçimde eklenmiştir. Aynı işlem altı öğrencinin altışar etkinliği için tekrarlanmış ve dosyalar uzmanların incelemesine hazır duruma getirilmiştir. Uzmanlara birer yönerge halinde etkinliğin amacı, etkinliğin içeriği, bilimsel yaratıcılık rubriği ve tasarım (ürün) değerlendirme rubrikleri verilerek birbirlerinden bağımsız olarak puanlama yapmaları istenmiştir.

\subsubsection{Bilimsel Yaratıcılık Rubriği}

Araştırmada kullanılan rubrik De Bono (1996)'nun yaratıcı düşünme becerisi aşamalarına (farkındalık, gözlem, strateji geliştirme ve yansıtma) göre uyarlanarak Barak ve Doppelt (2000) tarafından geliştirilen rubriktir. Rubrik, bu araştırmada konu edilen STEM etkinliklerine araştırmacılar tarafından uyarlanarak ve basamaklara uygun sorular geliştirilerek kullanılmıştır. Farkındalık basamağına uygun beceriye 10, gözlem basamağına uygun beceriye 20, strateji basamağına uygun beceriye 30, yansıtma basamağına uygun beceriye 40 puan verilerek rubrik 100 puan üzerinden değerlendirilmiştir. Basamaklarda birden fazla soru olduğunda bu puanlar sorunun zorluğuna göre dağıtılmıştır. Altı etkinlik için hazırlanan altı rubrik; bilimsel yaratıcılık konusunda çalışmış öğretim üyesi bir uzmanın görüşüne sunulmuş, düzenlemeler yapılmıştır.

\subsubsection{Tasarım (Ürün) Değerlendirme Rubriği}

Analiz aşamasında daha objektif bir değerlendirme sağlanabilmesi için araştırmacılar tarafından "Tasarım (Ürün) Değerlendirme Rubriği”" geliştirilmiştir. Rubriğin amacl, ortaya konan ürünü değerlendirmek ve "Bilimsel Yaratıcılık Rubriği"nin puanlamasına destek olmaktır. Bu rubrik de bilimsel yaratıcılık konusunda çalışmış öğretim üyesi bir uzmanın görüşüne sunulmuş ve gerekli düzenlemeler yapılmıştır. Tasarımların değerlendirmesinde belirlenen kriterler ise; "etkinlikte belirtilen amaca uygunluk, diğer tasarımlarla kıyaslandığında malzeme ve uygulama açısından ortaya konulan orijinallik, tasarımın işlevsel kalitesi, tasarımın görsel kalitesi ve etkinlikte önceden belirtilen koşullara uygunluk" olarak belirlenmiş̧ir. İlgili rubrik Ek-5'te sunulmuştur.

\subsubsection{Verilerin Analiz Aşamaları ve Güvenirlik}

Incelemenin ilk aşamasında grupların ürünlerine ait fotoğraflar ve sunum videoları incelenmiş, "Tasarım (Ürün) Değerlendirme Rubriği" ile yalnızca grup tasarımlarının (ürünlerinin) kalitesi değerlendirilmiş ve puanlanmıştır. İkinci aşamada ise bu rubrikten elde edilen öngörüyle öğrencilerin cevaplarındaki bilimsel yaratıcılık düzeylerini gösteren yorum kaliteleri "Bilimsel Yaratııılık Rubriği" aracılığıyla puanlanmıştır. "Tasarım (Ürün) Değerlendirme Rubriği" ile "Bilimsel Yaratıcılık Rubriği"nin uyum mantı̆̆ı şu şekilde açıklanabilir: "Tasarım (Ürün) Değerlendirme Rubriği"nden yani tasarım değerlendirmesinden düşük puan alan öğrenci eğer "Bilimsel Yaratıcılık Rubriği" cevaplarında tasarımının çok iyi olduğu yorumunda bulunmuşsa düşük puan almıştır. Fakat "Tasarım (Ürün) Değerlendirme Rubriği"nden düşük puan alıp "Bilimsel Yaratıcılık Rubriği"nde bunun nedenlerini, yaptıkları hataları açıklayabilen, tekrar yapması durumunda neler ekleyeceğini eleştirel biçimde açıklayabilen bir öğrenci ise yüksek puanla değerlendirilmiştir. Çünkü bu durum, öğrencinin yaptığı tasarımın niteliğinin farkında olduğu ve objektif olarak düşünebildiğini göstermektedir. Bahsedilen uyum mantığı; analiz yapacak uzmanlara belirtilmiş, puanlamada ürün kalitesi ve öğrencinin yorum kalitesi arasındaki ilişkinin değerlendirmesini yapmaları istenmiştir.

Değerlendirmelerin güvenirliği için araştırmacıların dışında üç uzmanın daha incelemesine tâbi tutularak analizci üçgenlemesi yapılmıştır. Analizci üçgenlemesi, birden fazla kişinin aynı nitel veriyi bağımsız olarak analiz etmesi ve ortaya çıkan bulguların karşılaştııılmasıdır (Patton, 2014). Uzmanlardan biri doktora çalışmasını bilimsel yaratıcılık konusunda yapmış bir öğretim üyesi, diğerleri ise bir devlet ortaokulunda çalışmakta olan iki fen bilimleri öğretmenidir.

Güvenirlik çalışması için bir öğrencinin tüm etkinliklerle ilgili bilimsel yaratıcılık sorularına verdiği cevaplar, öğretim üyesi olan uzmana inceletilmiştir. Böylece uzman, değerlendirme konusunda bir örnek oluşturmuştur. Öğretmen olan diğer iki uzman ise araştırmacının belirttiği yönergelere uygun ve birbirinden bağımsız olarak puanlama yapmışlardır. Üç uzmanın verdikleri puanların ortalaması alınarak öğrencilerin bilimsel yaratıcılık puanları belirlenmiştir. Bilimsel yaratıcılık 
uzmanının değerlendirmesini yaptı̆̆ı öğrencinin verilerinin analiz güvenirliği için SPSS programı ile yapılan analizde; üç uzmanın (araştırmacı ve iki fen bilimleri öğretmeni) verdiği puanların ortalaması ile bilimsel yaratıcılık uzmanının puanı arasındaki korelasyonun 0.898 olduğu, güvenirliğin ise 0.945 olduğu bulunmuştur. Böylece bilimsel yaratıcılık uzmanı ile diğer uzmanların puanları arasında bir uyum olduğu ve bulguların güvenilir kabul edilebileceği yorumu yapılmıştır.

\section{BULGULAR}

\subsection{Bilimsel Yaratıcılık Katmanlarına Göre Değerlendirme}

Farkındalık, gözlem, strateji ve yansıtma olarak belirtilen yaratıcılık katmanlarına ait puanlar ayrı ayrı değerlendirilerek grafikler oluşturulmuş, bulgular sunulmuştur.

\subsubsection{Farkındalık Katmanına Göre Puan Dağılımı}

Öğrencilerin 10 puan üzerinden değerlendirilen farkındalık katmanından aldığı puanlar Şekil 1'de görülmektedir.

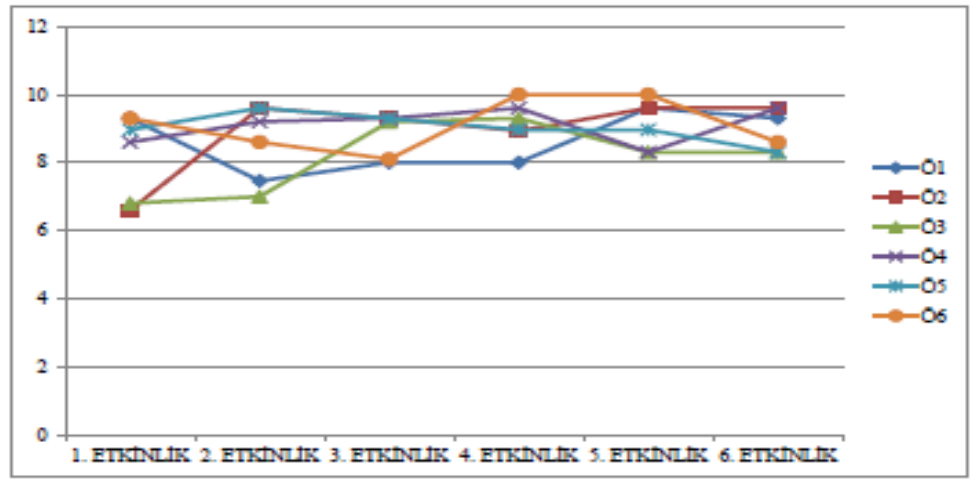

Şekil 1. Farkındalık Katmanı Puan Dağıımını Gösteren Çizgi Grafiği

Farkındalık katmanı puanlarında süreç boyunca artış ve azalış şeklinde dalgalanmalar görülmektedir. İlk etkinlik ile son etkinlikteki puanlar karşılaştırıldığında Ö2, Ö3 ve Ö4'te artış olduğu görülmektedir. Illk iki etkinlik-son iki etkinlik karşılaştırması yapıldığında ise yalnızca Ö5 in puanının azaldığı diğerlerinin puanlarının artış gösterdiği söylenebilir.

Ö1 kodlu öğrencinin ikinci ve beşinci etkinlikteki farkındalık katmanı sorularına ait cevapları değerlendirmeye bir örnek olacak şekilde sunulmuştur.

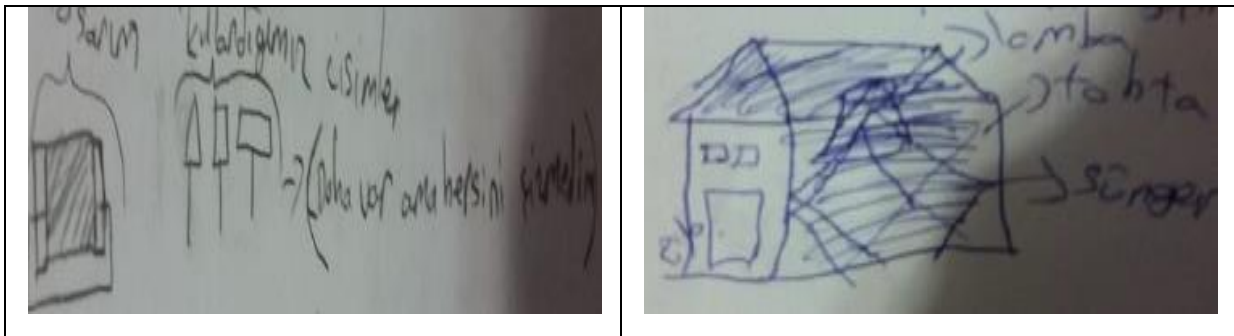

Şekil 2. Ö1 Kodlu Öğrencinin İki Etkinlikteki Farkındalık Sorusuna Ait Çizimleri

Öğrenci ikinci etkinlikte farkındalık katmanı sorusu için yaptığı çizimde (Şekil 2) tasarımın mekanizmasından bahsetmemiş, tasarımın bileşenlerini "karton ve tahta" olarak sınırlı biçimde açıklamış, böylece uzmanlardan 10 puan üzerinden ortalama 7,46 puan almıştır. Beşinci etkinlikteki farkındalık katmanı sorusu için yaptığı çizımde tasarımın parçalarını da oklarla belirtmiş, tasarımın bileşenlerini "tahta, çatı, zil, lamba, sünger (ses yalıtımı için)" biçiminde detaylı açıklamış, böylece uzmanlardan 10 puan üzerinden ortalama 9,6 puan almıştır. Öğrencinin iki etkinlik arasındaki 
cevaplarının farklılığından tasarımla ilgili farkındalığına dair bilimsel yaratıcılık düzeyinin geliştiği yorumuna ulaşılabilmektedir.

\subsubsection{Gözlem Katmanına Göre Puan Dağıımı}

Öğrencilerin 20 puan üzerinden değerlendirilen gözlem katmanından aldığı puanlar Şekil 3'te görülmektedir.

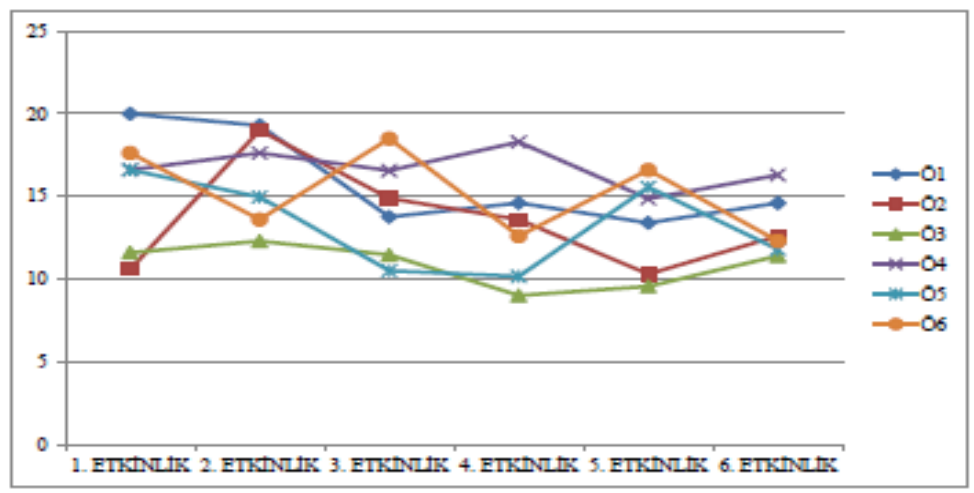

Şekil 3. Gözlem Katmanı Puan Dağılımını Gösteren Çizgi Grafiği

Öğrencilerin gözlem katmandaki puanları incelendiğinde yine dalgalanmalar görülmektedir. illk etkinlik ile son etkinliğin puanları karşılaştırıldığında yalnızca Ö2 kodlu öğrencide artış görülmektedir. İlk iki ile son iki etkinlik karşılaştırıldığında ise tüm öğrencilerin gözlem puanında azalma olduğu görülmektedir.

Ö1 kodlu öğrencinin birinci ve beşinci etkinlikteki gözlem katmanı sorularından biri ait cevapları değerlendirmeye bir örnek olacak şekilde sunulmuştur. Gözlem katmanına ait sorular tasarım konusundaki gözlemlere yönelik olduğundan her etkinlik için değişkenlik gösteren sorulardır. Fakat genel anlamda öğrencilerin cevaplarının bilimsel açıdan doğruluğu ve yorum kaliteleri açısından karşılaştırmalar yapılmışır.

Öğrenci ikinci etkinlikte "Tasarımınızla gıdaları koruyabildiniz mi? Hangi sonuçlara ulaştınız?" sorusuna "Evet gıdaları koruyabildik ama bir haftadan fazla dayanmıyor." cevabını vererek uzmanlardan 5 puan üzerinden 4 puan almıştır. Öğrenci beşinci etkinlikte "Evinizin ses yalıtımında hangi sonuçlara ulaştınız?" sorusuna "Ses yalıtımında sünger kullandık. Zilde kanarya sesi kullandık. Çok güzel ses çıkarıyor." cevabını vererek uzmanlardan 4 puan üzerinden 3,6 puan almıştır. Böylece öğrencinin yaptığı tasarımlara yönelik gözlemlerinin değerlendirmesi yapıımıştır.

\subsubsection{Strateji Katmanına Göre Puan Dağılımları}

Öğrencilerin 30 puan üzerinden değerlendirilen strateji katmanından aldığı puanlar Şekil 4'te görülmektedir.

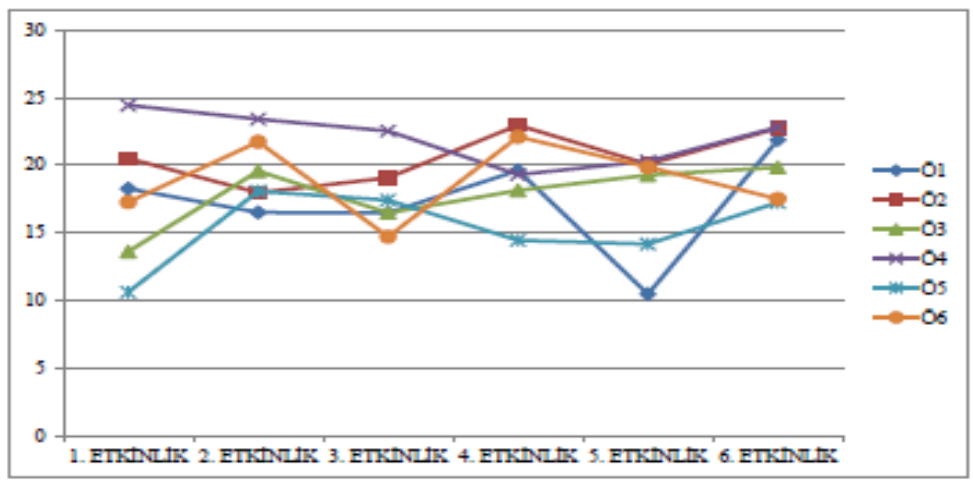

Şekil 4. Strateji Katmanı Puan Dağılımını Gösteren Çizgi Grafiği 
Öğrencilerin strateji katmanındaki puanları incelendiğinde yine dalgalanmalar görülmektedir. Ayrıca Ö4 haricindeki diğer öğrencilerin son etkinlikteki strateji puanının ilk etkinlikteki strateji puanından fazla olduğu görülmektedir. Ilk iki etkinlik-son iki etkinlik arasında karşılaştırma yapıldığında ise üç öğrencide (Ö2, Ö3, Ö5) artış, üç öğrencide (Ö1, Ö4, Ö6) azalma olduğu görülmektedir.

Ö1 kodlu öğrencinin birinci ve altıncı etkinlikteki strateji katmanı sorularından biri olan "Tasarımınızı nasıl test ettiniz? Nasıl sonuçlara ulaştınız?" sorusuna ait cevapları değerlendirmeye bir örnek olacak şekilde sunulmuştur.

Öğrenci birinci etkinlikte ilgili soruya "ilk başta elektrik devresini kurmaya çalıştık birkaç kere olmadı sonra yaptık ve lambanın içine yerleştirdik." cevabını vererek uzmanlardan 10 puan üzerinden ortalama 5,6 puan almıştır. Öğrenci altıncı etkinlikte ilgili soruya "Binaları yaptık ama güzel olmadı bozduk başka yaptık. Bu da güzel olmadı ama idare ettik." cevabını vererek uzmanlardan 10 puan üzerinden 7,6 puan almıştır. Öğrencinin iki etkinlik arasındaki cevaplarının farklılığından tasarımlarını test etme stratejisine dair bilimsel yaratıcılık düzeyinin geliştiği yorumuna ulaşılabilmektedir.

\subsubsection{Yansıtma Katmanına Göre Puan Dağılımları}

Öğrencilerin 40 puan üzerinden değerlendirilen yansıtma katmanından aldığı puanlar Şekil 5'te görülmektedir.

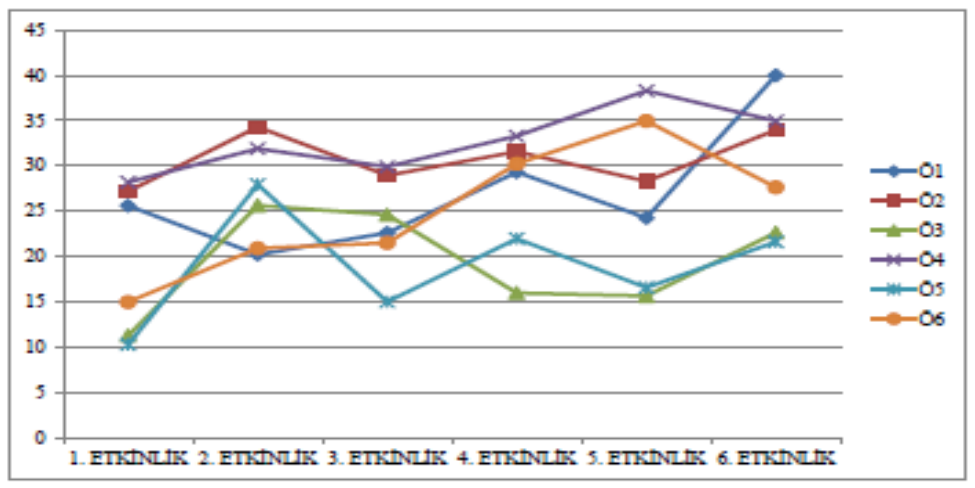

Şekil 5. Yansıtma Katmanı Puan Dağılımını Gösteren Çizgi Grafiği

Yansıtma katmanının puanları incelendiğinde görülen dalgalanmalarla beraber tüm öğrencilerin son etkinlikteki yansıtma puanının ilk etkinlikteki yansıtma puanlarından fazla olduğu görülmektedir. İlk iki etkinlik ile son iki etkinlik puanları karşılaştıııldığında ise tüm öğrencilerde artış görülmektedir. Ayrıca ilk iki etkinlik-son iki etkinlik karşılaştırmasında en büyük artışın Ö6 kodlu öğrencide, yani birinci dönemdeki fen dersi başarısı en düşük olan öğrencide olduğu tespit edilmiştir.

Ö1 kodlu öğrencinin ikinci ve altıncı etkinlikteki yansıtma katmanı sorularından biri olan "Geliştirme sürecindeki başarılarınız ve karşılaştığınız zorlukları açıklayınız" sorusuna ait cevapları değerlendirmeye bir örnek olacak şekilde sunulmuştur.

Öğrenci ikinci etkinlikte ilgili soruya "Zorluk yoktu." yanıtını vermiş, günlüğünde ise şu ifadelere yer vermiştir: "Bugün öğretmen gölge ile ilgili bir görev verdi. Biz arkadaşlarla düşündük taşındık bir şey yapmaya karar verdik. Ama daha belli olmadığından hala zorlanıyoruz. Bu görev bizi biraz zorlayacak." Öğrencinin konuyla ilgili cevapları değerlendirildiğinde görüşlerindeki uyuşmazlıklar nedeniyle uzmanlardan 10 puan üzerinden ortalama 4,3 puan almışır. Öğrenci altıncı final etkinliğinde ilgili soruya "Evleri yapmakta çok zorlandık olmadı beğenmedik. Sonunda yaptık ama yine de güzel olmadı." yanıtını vermiş, günlügünde ise şu ifadelere yer vermiştir: "Bugün kent projesini yetiştirmeye çalıştık yaptık ama hiç beğenmedim. Umduğum gibi olmadı. Çok fazla aksilik çıktı. Mesela yaptıklarımızı kaybettik. Çizmekte sorun yaşadık. Çiçek hep çamur olmuştu onunla uğraştık. Ama bitirdik. Çok kötü 
oldu. Çevreci bir şehir olmadı." Öğrencinin konuyla ilgili cevapları değerlendirildiğinde yaptığı özeleştirilerin doğruluğu nedeniyle uzmanlardan 10 tam puan almıştır. Öğrencinin iki etkinlik arasındaki cevaplarının farklılığından geliştirme sürecini yansıtmasına dair bilimsel yaratıcılık düzeyinin geliştiği yorumuna ulaşılabilmektedir.

Katmanlara göre sınıflandırmada tüm öğrencilerin verileri incelendiğinde; öğrencilerin farkındalık puanlarının genel olarak arttığı, gözlem puanlarının azaldığı, strateji puanlarının genel olarak arttığı, yansıtma puanlarının ise tüm öğrencilerde arttığı tespit edilmiştir. Böylece uygulanan STEM eğitiminin en üst yaratıcılık katmanı olan yansıtma becerisini en çok geliştirdiği sonucuna ulaşılmıştır.

\subsection{Etkinliklere Göre Değerlendirme}

Araştırmada uygulanan altı STEM etkinliğine ait dokümanların değerlendirilmesinden sonra her etkinlik için ayrı toplam puanlar çıkarılmış ve grafikler oluşturulmuştur. Her katmanın puanı farkı olduğundan burada yüzdelik olarak eşitlenerek verilmiştir. Çünkü buradaki amaç katmanların kendi içindeki değişiminin incelenmesidir. Etkinliklere göre değerlendirmeye ait bulgular Şekil 6'da verilmiştir.

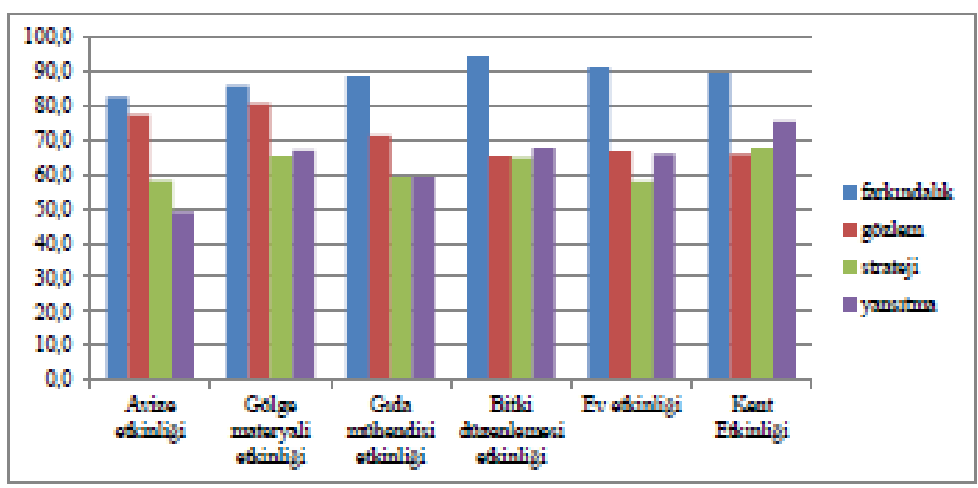

Şekil 6. Etkinliklere Göre Puan Dağılımını Gösteren Sütun Grafiği

Etkinliklere göre farkındalık puanının en fazla olduğu etkinliğin "Bitki Düzenlemesi Yapalım" etkinliği, gözlem puanının en fazla olduğu etkinliğin "Gölge Materyali Yapalım" etkinliği, strateji puanının en fazla olduğu etkinliğin final etkinliği olan "Ekolojik Yaşam Kenti" etkinliği, yansıtma puanının en fazla olduğu etkinliğin de "Ekolojik Yaşam Kenti" etkinliği olduğu görülmektedir. Ayrıca zamanla yani etkinlikler boyunca gözlem puanlarının düştüğü, strateji puanlarının ve yansıtma puanlarının arttığı değerlendirmesi de yapılabilmektedir.

\subsection{Toplam Bilimsel Yaratıcılık Puanlarına Göre Değerlendirme}

Toplam bilimsel yaratıcılık puanlarına göre değerlendirme için öğrencilerin 100 puan üzerinden her bir etkinlikten aldıkları yaratııılık puanları belirlenmiş ve Şekil 7'deki çizgi grafiği oluşturulmuştur.

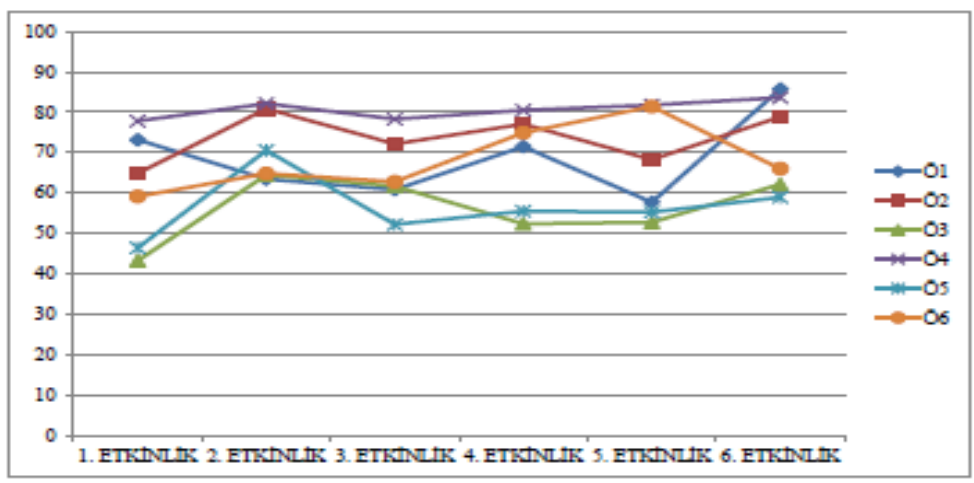

Şekil 7. Toplam Bilimsel Yaratıcılık Puan Dağıımını Gösteren Çizgi Grafiği 
Puanlar incelendiğinde ilk etkinlikteki yaratıcılık puanları sıralaması Ö4 > Ö1 > Ö2 > Ö 6 Ö5 > Ö3 iken, son etkinlikteki yaratıcılık puanları sıralamasının Ö1 > Ö4 > Ö2 > Ö6 > Ö3 > Ö5 olduğu görülmektedir. Dolayısıyla öğrenciler bireysel anlamda kıyaslandıklarında ilk iki ve son ikide yer alan öğrencilerin kendi aralarında yer değiştirdikleri görülmekte, bunun dışında önemli bir düşüş veya artış görülmemektedir. Öğrencilerin bilimsel yaratıcılık toplam puanları süreç içerisinde dalgalanmalar gösterse de tamamının son etkinlikteki yaratıcılık puanı ilk etkinlikteki bilimsel yaratıcılık puanından fazladır. Ö1 kodlu öğrenci haricindeki diğer öğrencilerin en düşük bilimsel yaratıcılık puanının ilk etkinlikte olduğu görülmektedir. Böylece öğrencilerin birbirlerine sıralamalarında önemli bir değişme olmadığı görülmektedir. Yani ilk etkinlikteki bilimsel yaratıcılık potansiyeli diğerlerine göre yüksek olan öğrenciler yine diğerlerine göre yüksek düzeyde performans göstermişler, başlangıçta düşük yaratıcılık düzeyine sahip olan öğrenciler de yüksek performans gösterenlerle aynı seviyeye gelememiştir. Fakat öğrencilerin kendi süreçleri içerisinde yaratıcılıklarının gelişim gösterdiği söylenebilmektedir. Sonuç olarak; öğrencilerin bilimsel yaratıcılık konusunda birbirlerine göre sıralamaları genel olarak korunmuş, kendi yaratıcılık performansları ise süreç boyunca gelişim göstermiştir.

\section{SONUÇ, TARTIŞMA VE ÖNERILER}

\subsection{Sonuçlar}

Bilimsel yaratıcılık katmanlarına göre sınıflandırmada; öğrencilerin farkındalık puanlarının genel olarak arttığı, gözlem puanlarının azaldığı, strateji puanlarının genel olarak arttığı, yansıtma puanlarının ise tüm öğrencilerde arttı̆̆ı sonucuna varılmıştır. Böylece uygulanan STEM eğitiminin en üst bilimsel yaratıcılık katmanı olan "yansıtıcı düşünme becerisi"ni geliştirmede daha çok etkili olduğu sonucuna ulaşılmıştır. STEM etkinliklerine göre sınıflandırmada; yaratıcılığın üst katmanları olan strateji geliştirme ve yansıtıcı düşünmeyi en çok geliştiren etkinliğin 6. final etkinliği olduğu ve en başarılı etkinlik olduğu belirlenmiştir. Bilimsel yaratıcılık toplam puanlarına göre değerlendirmede ise; tüm öğrencilerin son etkinlikten aldıkları bilimsel yaratıcılık puanının ilk etkinlikten aldıkları bilimsel yaratııılık puanından fazla olduğu bulgusuna ulaşılmıştır. Ayrıca öğrencilerin bilimsel yaratıcılık konusunda birbirlerine göre sıralamalarının genel olarak korunduğu, bireysel anlamda bilimsel yaratıcılık performanslarının ise süreç boyunca gelişim gösterdiği sonucuna varılmıştır.

\subsection{Tartışma}

Alanyazında mühendislik uygulamalarının (Cantrell ve diğerleri, 2006; Samuels ve Seymour, 2015) ve STEM eğitiminin (Havice, 2015) yaratıcılık üzerine olumlu etkisi olduğunu belirten araştırmalar bulunmaktadır. Alan yazındaki deneysel araştırmalar da bu araştırmanın sonucunu desteklemektedir. Suescun-Florez ve diğerleri (2013) mühendislik tasarım programı sonucunda ilköğretim öğrencilerinin yaratıcılık için ilham sahibi olduklarını belirtmişlerdir. Ceylan (2014) ortaokul 8. sınıf öğrencileriyle gerçekleştirdiği STEM etkinliklerinin sonucunda deney grubu öğrencilerinin yaratıcılık becerilerinin kontrol grubundaki öğrencilere göre daha iyi olduğunu ve STEM eğitiminin yaratıcılık becerileri üzerine orta düzeyde bir etkisinin olduğu sonucuna varmıştır.

Alanyazında bilimsel yaratııılı̆̆ın gelişimiyle ilgili özellikle STEAM (STEM+sanat) araştırmaları dikkat çekmektedir. SoonBeom, Dongsoo ve TaeWuk (2011) ilkokul öğrencilerinin STEAM eğitimiyle yaratıcı kişilik özelliklerinin geliştiğini tespit etmişlerdir. Lee ve Lee (2013) fen dersinde uyguladıkları STEAM eğitiminin ilköğretim öğrencilerinin yaratıcılık gelişimini olumlu etkilediğini bulmuşlardır. Kim ve diğerleri (2014) ilköğretim 6. sınıf öğrencilerine STEAM eğitimi uyguladıkları araştırmalarında deney grubu öğrencilerinin yaratıcılıklarının kontrol grubundakilere göre daha çok geliştiğini belirtmişlerdir. Gülhan ve Şahin (2018) STEAM eğitimiyle 7. sınıf öğrencilerinin bilimsel yaratıcılık düzeylerinin geliştiğini belirtmişlerdir. Bu araştırmalar, STEM eğitimine sanat katkısı ile de öğrencilerin bilimsel yaratııılığın geliştiğini göstermektedir. 
Bilimsel yaratıcılık katmanlarına göre değerlendirmede en önemli gelişmenin "yansıtıcı düşünme" katmanında olması araştırmanın önemli bir sonucudur. Çünkü bu beceri katmanı, bilimsel yaratıcılığın en üst beceri içeren katmanı olarak değerlendirilmektedir. Benzer şekilde Gülhan ve Şahin (2018) STEAM etkinliklerinin de en çok yansıtıcı düşünme katmanında gelişmeyi sağladığını belirtmişlerdir. Bir alt basamak olan "strateji geliştirme" katmanında her öğrencide olmasa da genelde artışların görülmesi yine olumlu bir sonuçtur. Fakat gözlem katmanında tüm öğrencilerin puanında azalış, farkındalık katmanında ise genel olarak artış görülmüştür. Bu katmanlarda daha olumsuz sonuçlar alınmasının nedeni etkinliklerin farklılı̆ıyla beraber bilimsel yaratıcılık sorularının da farkılış̧ması ve giderek zorlaşmış olmasıdır. Strateji ve yansıtma katmanlarına ait sorular tüm etkinliklerde aynı iken, farkındalık ve gözlem katmanlarına ait sorular konu alanına göre değişiklik göstermiş̧ir. Bu durum, süreçteki karşılaştırma zorluğunu da beraberinde getirmiştir. Araştırma sonuçlarında dikkate değer bir diğer nokta ise, yaratıcılık katmanı puanına göre sıralamada ilk iki etkinlik ile son iki etkinlik arasında puanı en çok artış gösteren öğrencinin birinci dönemdeki fen bilimleri dersi notu en düşük olan öğrenci olmasıdır. Bu sonuç, ders başarısı diğer öğrencilere göre düşük olan bir öğrencinin de STEM etkinlikleriyle bilimsel yaratıcılığın en üst katmanı olan yansıtma becerisini dahi belirgin şekilde geliştirebildiğini göstermektedir.

Etkinliklere göre değerlendirmede bilimsel yaratıcılık puanlarını geliştirme açısından en başarılı etkinliğin 6. final etkinliği olması, hem zamanla öğrencilerin yaratıcılığın üst katmanındaki becerilerinin geliştiğini hem de en kapsamlı ve zor olan bu etkinliğin öğrenciler tarafından verimli biçimde değerlendirildiğini göstermektedir. Öğrencilerin bilimsel yaratıcılık puanlarının süreç boyunca bireysel değerlendirmesinde ise; tüm öğrencilerin son etkinlikteki yaratıcılık puanının ilk etkinlikteki yaratıcılık puanından fazla olması süreçteki gelişimlerini ortaya koymaktadır. Böylece öğrencilerin yaratıcılık potansiyellerinin STEM eğitimi ile daha da geliştirilebildiği yorumuna ulaşılabilir. Bilimsel yaratıcılık düzeyi diğer öğrencilere göre daha az olan öğrencilerin fazla gelişememesinin nedenleri, etkinliklere ilgisizlikleri veya etkinliklerin zaman içerisinde zorlaşması olarak değerlendirilebilir. Etkinliklerin git gide aşamalarla kapsamı genişlediği durumu göz önüne alındığında bilimsel yaratıcılık puanı artan öğrencilerin görünenden daha zor bir durumu aştıkları söylenebilmektedir.

Araştırmada bilimsel yaratııılık gelişimleri incelenen öğrencilerin puanlarının süreç içerisinde artış azalış olarak dalgalanmalar gösterdikleri tespit edilmiştir. Bu durumun etkinliklerin ve buna bağlı olarak yöneltilen soruların farklılığı ve giderek zorlaşmasından kaynaklandığı düşünülmektedir. Öğrenciler, gittikçe zorlaşan ve kapsamı genişleyen soruları yazılı olarak cevaplamada sıkıntılar yaşamış ve düşüncelerini yeterince yansıtamamış olabilirler. illk etkinliklerde az sayıdaki sorulara daha istekli olarak cevap vermiş, fakat sorular zorlaştıkça yorgunluk nedeniyle görüşlerini daha kısa cümlelerle ifade etmiş olabilirler. Bu durumla ilgili, öğrencilerden yazılı yanıt alma yerine görüşmelerle sözlü olarak daha verimli yanıtlar alınabileceği önerisinde bulunulmaktadır. Bu araştırma, deneysel süreçleri de içeren karma modelli bir araştırmanın parçası olduğundan bu öneri gerçekleştirilememiştir. Fakat daha az sayıda öğrencinin yer aldığı eylem araştırmalarında belirtilen öneri gerçekleştirilebilir.

Araştırmanın zaman sınırlılı̆̆ da etkinliklerin gerçek amacına tam anlamıyla ulaşmasında engel çıkarmış olabilir. Öğrenciler, süreçte sık sık projelerini yetiştirme konusunda sıkıntılar yaşadıklarını gerek sözlü gerekse günlükleri aracılığıyla ifade etmişlerdir. Bu problemin en aza indirilebilmesi için ders müfredatının el verdiği ölçüde daha geniş zaman sağlanabilir. Fakat burada tek sorunun zaman sınırıı ı̆̆ı da olmadığı, öğrencilerin çalışma hızı ve planlama yeteneklerinin de önem arz ettiği düşünülmektedir. Baran, Canbazoğlu Bilici, Mesutoğlu ve Ocak (2016) da araştırmalarında bazı öğrencilerin zaman sınırlamasına takıldı̆ıını STEM etkinliklerini tamamlamada zorluk çektiklerini belirtmişler, bu noktada planlamanın da önemli bir tasarım becerisi olduğu yorumunu yapmışlardır. Dolayısıyla ne kadar geniş zaman ayrılırsa ayrılsın, durum yine öğrencilerin planlama becerilerine bağlı kalmaktadır. Bu durumun da öğrencilerin proje çalışmalarına yeterince alışkın olmamalarından kaynaklandığı düşünülmektedir. Bu nedenle öğrencilerin planlama, zamanı etkin 
kullanma becerilerinin gelişimi için de ek rehberlik hizmetleri sağlanmasıyla daha etkili sonuçlara ulaşılabilir.

\section{3 Öneriler}

- Araştırmanın başlığında da belirtildiği gibi etkinlikler Fen Bilimleri dersi kazanımları merkeze alınarak ve diğer STEM alanlarının kazanımları ile eşleştirilerek geliştirilmiştir. Daha geniş ve esnek müfredatın uygulandığı okullarda diğer STEM alanlarının kazanımlarıyla beraber tam bir entegrasyon gerçekleştirilebilir.

- Bu araştırma 2013-2014 eğitim-öğretim yılında uygulamaya alınan Fen Bilimleri dersi müfredatına yönelik hazırlandığından, 2018-2019 eğitim-öğretim yılında uygulanmaya başlanan Fen Bilimleri dersi müfredatında değişen ünite içerikleri sıralamalarına göre STEM etkinlikleri uyarlanarak geliştirilmelidir.

- STEM eğitimiyle ilgili farkı etkinlikler kullanılıp farkı değişkenler (akademik başarı, kavramsal anlama, tutum, motivasyon, algı vb.) ele alınarak deneysel çalışmalar gerçekleştirilmelidir.

- Bilimsel yaratıcılık değişkeniyle ilgili eylem araştırmaları gerçekleştirilerek gözlem ve görüşmelerin de yer aldığı daha derinlemesine incelemeler yapılmalıdır. Bununla beraber nicel testlerin ağırlıkta olduğu deneysel araştırmalarla daha genellenebilir sonuçlar da elde edilmelidir. Her iki araştırma türünün de bilimsel yaratıcılıkla ilgili çıktıları genel-özel durum karşılaştırmalarında önemli olacaktır.

Öğrencilerin STEM eğitiminde proje gerçekleştirirken zaman yönetimlerini doğru şekilde yapabilmeleri için ek rehberlik sağlanmalıdır.

\section{Kaynakça}

Aktamış, H. ve Ergin, Ö. (2006). Fen eğitimi ve yaratıcılık. Dokuz Eylül Üniversitesi Buca Eğitim Fakültesi Dergisi, 20, 77-83.

Baran, E., Canbazoğlu Bilici, S., Mesutoğlu, C. ve Ocak, C. (2016). Moving STEM beyond schools: Students' perceptions about an out-of-school STEM education program. International Journal of Education in Mathematics, Science and Technology, 4(1), 9-19.

Barak, M. ve Doppelt, Y. (2000). Using portfolios to enhance creative thinking. The Journal of Technology Studies, 26(2), 16-25.

Barcelona, K. (2014). 21st century curriculum change initiative: A focus on STEM education as an integrated approach to teaching and learning. American Journal of Educational Research. 2(10), 862-875.

Barlex, D. (2007). Creativity in school design \& technology in England: A discussion of influences. International Journal of Technology and Design Education, 17(2), 149-162.

Baysal, Z. N., Kaya, N. B. ve Üçüncü, G. (2013). Illkokul dördüncü sınıf öğrencilerinde bilimsel yaratıcılık düzeyinin çeşitli değişkenler açısından incelenmesi. Eğitim Bilimleri Dergisi, 38, 55-64.

Cantrell, P., Pekcan, G., Itani, A. ve Velasquez-Bryant, N. (2006). The effects of engineering modules of student learning in middle school science classrooms. Journal of Engineering Education, 95(4), 301-309.

Ceylan, S. (2014). Ortaokul fen bilimleri dersindeki asitler ve bazlar konusunda fen, teknoloji, mühendislik ve matematik (FeTeMM) yaklaşımı ile öğretim tasarımı hazırlanmasına yönelik bir çalışma. Yayımlanmamış yüksek lisans tezi, Uludağ Üniversitesi, Eğitim Bilimleri Enstitüsü, Bursa.

Charyton, C. (2015). Creative engineering design: The meaning of creativity and innovation in engineering. In C. Charyton (Ed.), Creativity and innovation among science and art (pp.135-152). London, Springer-Verlag. 
Court, A. W. (1998). Improving creativity in engineering design education. European Journal of Engineering Education, 23(2), 141-154.

Cunningham, C. M. ve Hester, K. (2007). Engineering is Elementary: An engineering and technology curriculum for children. Presented at the ASEE Annual Conference and Exposition, Honolulu, HI. Retrieved from: http://eie.org/eie-curriculum/research/articles/engineeringelementaryengineering-and-technology-curriculum

Çellek, T. (2002). Yaratıcılık ve eğitim sistemimizdeki boyutu. Bilim, Eğitim ve Düşünce Dergisi, 2(1), 2 4.

Çepni, S. (2010). Araştırma ve proje çalışmalarına giriş (5. baskı). Trabzon.

Daugherty, M. K. (2009). The "T" and "E" in STEM. In ITEEA (Eds.), The Overlooked STEM Imperatives: Technology and Engineering (pp. 18-25). Reston, VA: ITEEA.

Driggs Lark, C. E. (2015). Identifying pioneers of tomorrow: A study of the relationship between middle school students' innovator skills and STEM interests. Doctoral dissertation. Omaha, NE. (UMI no. 3712267).

Ferrari, A., Cachia, R. ve Punie, Y. (2009). Innovation and Creativity in Education and Training in the EU Member States: Fostering Creative Learning and Supporting Innovative Teaching: Literature review on Innovation and Creativity in E\&T in the EU Member States (ICEAC). Joint Research Centre European Commission. Retrieved from: http://ftp.jrc.es/EURdoc/JRC52374 TN.pdf

Fisher, R. (2004). What is creativity? In R. Fisher \& M. Williams (Eds.), Unlocking creativity: Teaching across the curriculum. (pp. 6-20). Great Britain: David Fulton Publishers.

Gomez, A. ve Albrecht, B. (2014). True STEM Education. Technology and Engineering Teacher, 73(4), 816.

Gülhan, F. ve Şahin, F. (2018). STEAM (STEM+Sanat) etkinliklerinin 7. sınıf öğrencilerinin akademik başarı, STEAM tutum ve bilimsel yaratıcılıklarına etkisi. Journal of Human Sciences, 15(3), 16751699. doi:10.14687/jhs.v15i3.5430

Havice, W. L. (2015). Integrative STEM education for children and our communities. The Technology Teacher, 75(1), 15-17.

Hu, W. ve Adey, P. (2002). A scientific creativity test for secondary school students. International Journal of Science Education, 24(4), 389-403.

Hughes, J. (Apr 10, 2017). STEM, STEAM, and where creativity fits into the mix. Retriewed from: https://www.masterstudies.com/article/STEM-STEAM-and-Where-Creativity-Fits-into-the-Mix/

Karakuş, M. (2001). Eğitim ve yaratıcılık. Eğitim ve Bilim, 26(119), 3-7.

Katanski, D. (2013). Bridging the creativity and STEM crisis. ASQ Advancing the STEM Agenda Conference. Grand Valley State University- Grand Rapids, Michigan - June 3-4, 2013. Retrieved from: http://rube.asq.org/edu/2013/04/career-development/bridging-the-creativityand-stemcrisis.pdf

Kim, D., Ko, D., Han, M. ve Hong, S. (2014). The effects of science lessons applying STEAM education program on the creativity and interest levels of elementary students. Journal of the Korean Association for Science Education, 34(1), 43-54.

Larkin, T. L. (2015). Creativity in STEM education: Reshaping the creative project. International Conference on Interactive Collaborative Learning (ICL). (pp. 1184-1189). Florence, Italy.

Lee, S. ve Lee, H. (2013). The effects of science lesson applying STEAM education on the creativity and science related attitudes of elementary school students. Journal of Korean Elementary Science Education, 32(1), 60-70.

National Advisory Committee on Creative and Cultural Education (NACCCE). (1999). All our futures: Creativity, culture and education. London: DFEE.

Patton, M. Q. (2014). Nitel araştırma ve değerlendirme yöntemleri (3. baskıdan çeviri). (M. Bütün ve S. B. Demir Çev. Eds). Ankara: Pegem Akademi. 
Reeve, E. M. (2015). STEM Thinking! Technology and Engineering Teacher, 74(4), 8-16.

Roberts, A. (2012). A justification for STEM education. The Technology and Engineering Teacher, 71(8), 1-5. Retrieved from: http://www.iteaconnect.org/mbrsonly/Library/TTT/TTTe/04-12roberts.pdf

Robinson, D. ve Koshy, V. (2004). Creative mathematics: allowing caged birds to fly. In R. Fisher \& M. Williams (Eds.), Unlocking creativity: Teaching across the curriculum. (pp. 68-81). Great Britain: David Fulton Publishers.

Samuels, K. ve Seymour, R. (2015). The middle school curriculum: Engineering anyone? Technology and Engineering Teacher, 74(6), 8-12.

SoonBeom K., Dongsoo N. ve TaeWuk L. (2011). The effects of convergence education based STEAM on elementary school students' creative personality. T. Hirashima et al. (Eds.) (2011). Proceedings of the 19th International Conference on Computers in Education. Chiang Mai, Thailand: Asia-Pacific Society for Computers in Education.

Sönmez, V. ve Alacapınar F. G. (2011). Örneklendirilmiş bilimsel araştırma yöntemleri. Ankara: Anı Yayıncılık.

Suescun-Florez, E. A., Cain, R. F., Kapila, V. ve Iskander, M. G. (2013, June). Bringing soil mechanics to elementary schools. Paper presented at 2013 ASEE Annual Conference, Atlanta, Georgia. Retrieved from: https://peer.asee.org/19268

Valenti, S. S., Masnick, A. M., Cox, B. D. ve Osman, C. J. (2016). Adolescents' and Emerging Adults' Implicit Attitudes about STEM Careers: "Science is Not Creative" Science Education International, 27(1), 40-58.

Yamaç, K. (2001). Nedir bu inovasyon? Üniversite ve Toplum, 1(3), 6. http://www.universitetoplum.org/text.php3?id=38

Yatt, B. ve McCade, J. (2011). Defining creativity and design. In S. A. Warner \& P. R. Gemmill (Eds.), Creativity and design in technology \& engineering education. (pp. 32-68). Council on technology teacher education. 60th yearbook. United States of America.

Yıldırım A. ve Şimşek H. (2008). Sosyal bilimlerde nitel araştırma yöntemleri (7. Baskı). Ankara: Seçkin Yayıncılık. 


\section{EK-1: EKOLOJiK YAŞAM KENTI PROJESI (FINAL ETKINLIĞi)}

\section{Problem senaryosu}

Artık kentimizi kurmaya başlıyoruz. Adı 'Ekolojik Yaşam Kenti'. Bu çiftlikteki iddiamız insanların, hayvanlar ve bitkilere zarar vermeden sağlıklı bir ekosistem oluşturabilmeleri. İçerisinde karada, suda yaşamını sürdüren birçok hayvanın, bitkilerin olduğu böyle bir sistemde insanların gıda, barınma, enerji gibi gereksinimleri nasıl giderilebilir? Önce şehrimizin krokisini çizelim daha sonra maketimize başlayalım.

Problem: Bir çevre mühendisi, inşaat mühendisi, şehir planlamacısı gibi düşünerek düzenli şekilde işleyen bir ekosistemi nasıl oluşturabiliriz?

Koşullar:

- Önceki etkinlikte yaptığınız ev maketini kullanmalısınız.

- Önceki etkinlikte peyzajını yaptığınız bitki tasarımını kullanmalısınız.

- Evi bitkilerin güneş almasını engellemeyecek şekilde güney-kuzey yönleri ayarlayarak yerleştirmelisiniz.

- $\quad$ içerisinde su bulunan bir alan oluşturmalısınız.

- Çeşitli hayvanlar bulunmalı.

- Canlılar doğal yaşam alanlarını temsil etmeli (kara, su)
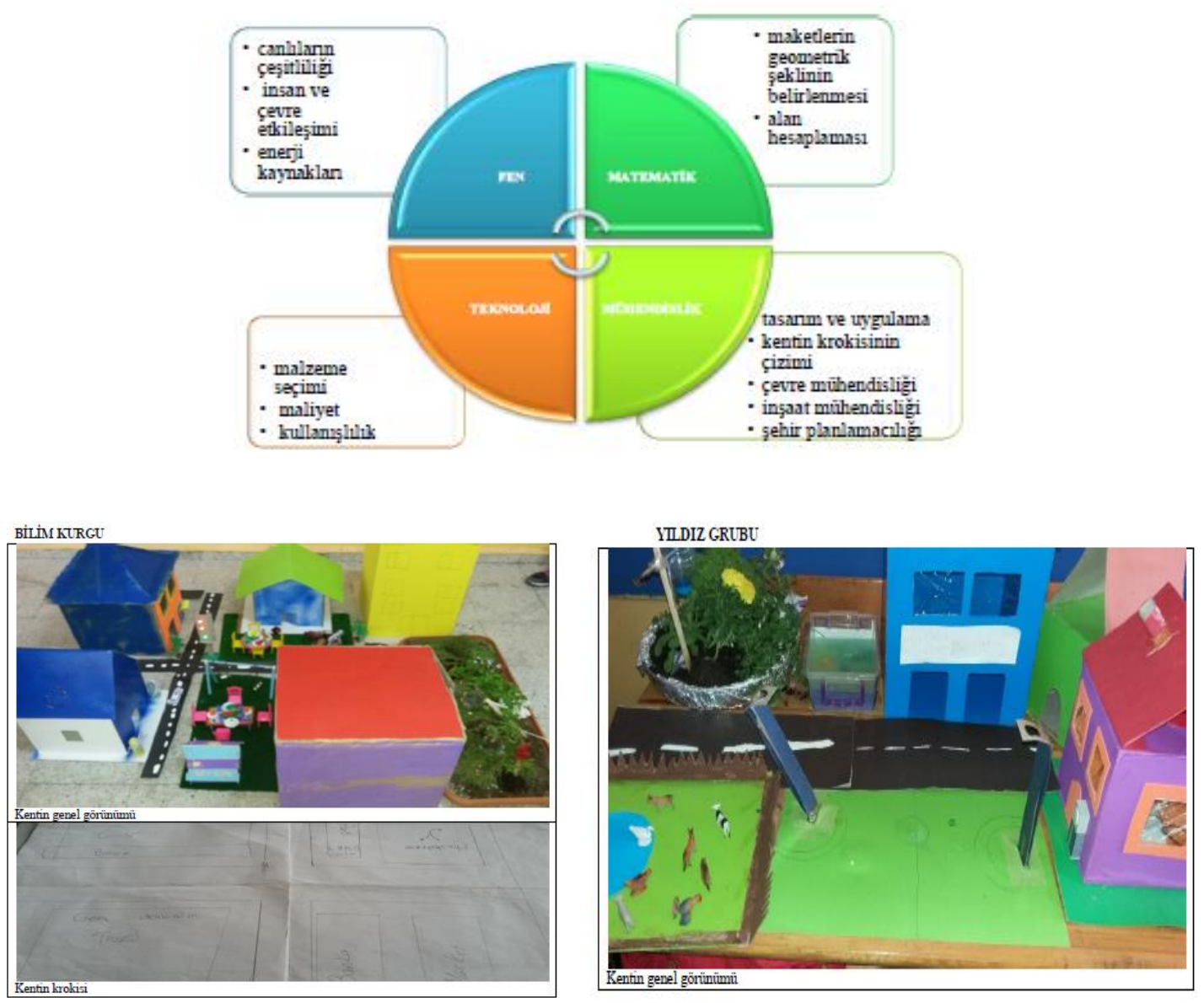


\section{EK-2: EKOLOJiK YAŞAM KENTi PROJESI (FINAL ETKINLIĞi) BíLiMSEL YARATICILIK RUBRiĞi SORULARI}

\begin{tabular}{|c|c|c|}
\hline $\begin{array}{l}\text { Düşünce } \\
\text { katmanları }\end{array}$ & Görevin bileşenleri & $\begin{array}{l}\text { Puan } \\
\text { değeri }\end{array}$ \\
\hline 1. Farkındalık & $\begin{array}{l}\text { Tasarımınızın çizimini yapınız. } \\
\text { Tasarımınızın temel bileşenlerini yazınız. }\end{array}$ & $\begin{array}{l}10 p \\
5-5\end{array}$ \\
\hline 2. Gözlem & $\begin{array}{l}\text { Kendinizi biyolog gibi düşünerek oluşturduğunuz yaşam } \\
\text { alanlarındaki canlı grupları hakkında neler söyleyebilirsiniz? } \\
\text { Kendinizi matematikçi gibi düşünerek yaptığınız maketlerin } \\
\text { geometrik şekillerini belirtip ve alanlarını hesaplayabilir misiniz? } \\
\text { Kendinizi çevre mühendisi gibi düşünerek oluşturduğunuz yaşam } \\
\text { alanları hakkında neler söyleyebilirsiniz? } \\
\text { Kendinizi gıda mühendisi gibi düşünerek oluşturduğunuz yaşamın } \\
\text { besin zinciri neler söyleyebilirsiniz? } \\
\text { Kendinizi enerji mühendisi gibi düşünerek oluşturduğunuz yaşam } \\
\text { alanındaki enerji üretimiyle ilgili söyleyebilirsiniz? } \\
\text { Kendinizi inşaat mühendisi gibi düşünerek oluşturduğunuz yerleşim } \\
\text { yerleri hakkında neler söyleyebilirsiniz? } \\
\text { Kendinizi peyzaj mimarı gibi düşünerek oluşturduğunuz yaşam } \\
\text { alanları hakkında neler söyleyebilirsiniz? } \\
\text { Kendinizi akustik (ses) mühendisi gibi düşünerek oluşturduğunuz } \\
\text { yaşam alanları hakkında neler söyleyebilirsiniz? } \\
\text { Kendinizi elektrik mühendisi gibi düşünerek oluşturduğunuz yaşam } \\
\text { alanları hakkında neler söyleyebilirsiniz? } \\
\text { Kendinizi şehir planlamacısı gibi düšünerek oluşturduğunuz yaşam } \\
\text { alanları hakkında neler söyleyebilirsiniz? }\end{array}$ & $\begin{array}{l}20 p \\
2 \text { şer } \\
\text { puan }\end{array}$ \\
\hline 3. Strateji & $\begin{array}{l}\text { Tasarımınızda hangi malzemeleri kullandınız, nedenlerini } \\
\text { açıklayınız? } \\
\text { Tasarımınızı hangi aşamalardan geçerek gerçekleştirdiniz? } \\
\text { Tasarımınızı nasıl test ettiniz? Nasıl sonuçlara ulaştınız? } \\
\text { Diğer grupların tasarımları ile kendi grubunuzun tasarımını } \\
\text { karşılaştırınız. Eksik veya üstün yönlerini yazınız. }\end{array}$ & $\begin{array}{l}30 p \\
5-5- \\
10-10\end{array}$ \\
\hline 4. Yansitma & $\begin{array}{l}\text { Hayal ettiğiniz tasarıma ulaşabildiniz mi? Açıklayınız. } \\
\text { Geliştirme sürecindeki başarılarınız ve karşılaştığınız zorlukları } \\
\text { açıklayınız. } \\
\text { Tasarımınızı en baştan yapmayı düşündüğünüzde planlama ve } \\
\text { uygulaması çin hangi önerilerde bulunursunuz? }\end{array}$ & $\begin{array}{l}40 p \\
10-10- \\
20\end{array}$ \\
\hline
\end{tabular}




\section{EK-3: GÜNLÜK SAYFASI ÖRNEĞi}

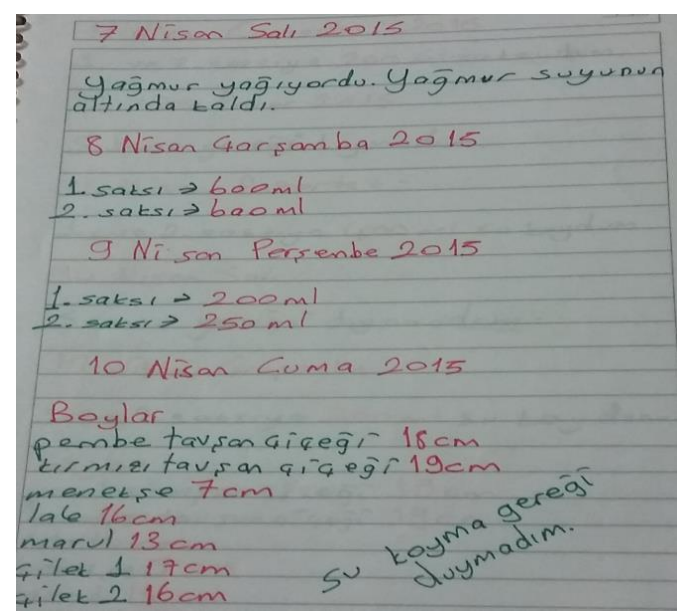

Bugün okulda çiçek deneyimizi bitirdik. Bu deneyden güzel bir sonuç çıkaracağıma inanıyorum (24.03.2015 tarihli günlükten)

\section{EK-4: TASARIM KÂĞIDI ÖRNEĞİ}

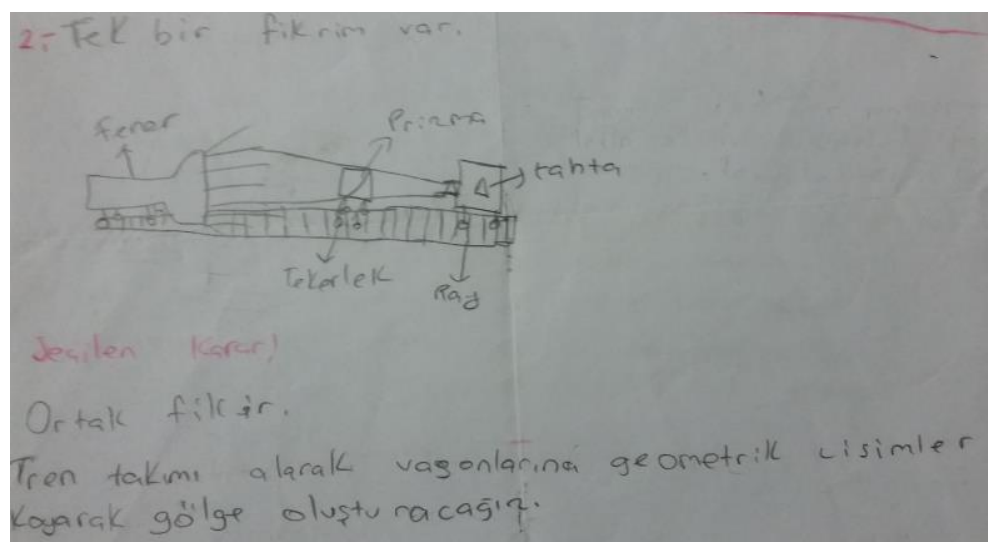

EK-5: TASARIM (ÜRÜN) DEĞERLENDIRME RUBRIĞi

\begin{tabular}{|l|l|l|l|l|l|}
\hline KRITERLER & Çok zayıf (1) & Zayıf (2) & Orta (3) & İyi (4) & Çok iyi (5) \\
\hline $\begin{array}{l}\text { Tasarımın amaca } \\
\text { uygunluğu }\end{array}$ & & & & & \\
\hline $\begin{array}{l}\text { Tasarımın } \\
\text { orijinalliği }\end{array}$ & & & & & \\
\hline $\begin{array}{l}\text { Tasarımın } \\
\text { işlevselliği }\end{array}$ & & & & & \\
\hline $\begin{array}{l}\text { Tasarımın görsel } \\
\text { kalitesi }\end{array}$ & & & & & \\
\hline $\begin{array}{l}\text { Tasarımın } \\
\text { kriterlere } \\
\text { (koşullara) } \\
\text { uygunluğu }\end{array}$ & & & & & \\
\hline
\end{tabular}




\section{Extended Summary}

\section{Purpose}

The STEM education how it can be applied in the class and the potential impacts on the students has been an important research topics. Scientific creativity is one of the key skill areas that are thought to be related to STEM (Barcelona, 2014; Cantrell, Pekcan, Itani and Velasquez-Bryant, 2006; Charyton, 2015; Daugherty, 2009; Driggs Lark, 2015; Havice, 2015; Larkin, 2015; Roberts, 2012; Samuels and Seymour, 2015). In this research, it is aimed to investigation that the effect of STEM integration on the scientific creativities of middle school 5 th grade students.

\section{Method}

The case study was used in the research. The research was applied in a secondary school in Istanbul in 2014-2015 academic year. In this research at three units that six STEM focused activities were applied for twelve weeks. "Let's Design Our Chandelier" and "Let's Make Shadow Materials" activities for "Light and Sound" unit; "Let's Make Plant Arrangement" and "Becoming a Food Engineer" activities for "Let's Learn the World of Alive" unit; "Let's Design Our Home" activity for "Electricity in our Life" unit and; "Ecological Living City Project" as final project for all the units was designed by the researchers. Activities that started with a problem scenario that was appropriate for the topic include science-mathematics-engineering-technology items. Engineering design process steps (ask, imagine, plan, create, improve) were used to implemented the activities (Cunningham and Hester, 2007). Qualitative documents were obtained in the research. That data collection tools were used in research; "Scientific Creativity Questions", "Student Diaries", "Design Papers", "Photographs and Presentation Videos". These documents have been analyzed by "Scientific Creativity Rubric" (Barak and Doppelt, 2000) and "Product Evaluation Rubric". "Scientific Creativity Rubric" is adapted to STEM activities by researchers. "Product Evaluation Rubric" was developed by researchers for scoring qualities of designs. 6 rubrics prepared for 6 activities; an expert who worked on scientific creativity was presented to the opinion and the regulations were made. Activities and data collection tools have been applied to the all class consist of 28 students, but in the content analysis of documents, were maximum diversity sampling and were examined total of 6 students' documents from each group. The students were selected heterogeneously according to their achievement and gender. Creative thinking skills (awareness, observation, strategy, reflection) were evaluated according to their stages. In order to ensure the reliability of the evaluation, its were subjected to examination by three experts besides the researchers. The experts have made scoring by looking at the design quality and the harmony of student comments. The correlation between the score of the scientific creativity expert and the scorers was found to be 0.898 , and the reliability was found to be 0.945 . Scientific creativity scores of the students were determined by taking the average of the scores given by the experts.

\section{Findings}

When the scores of the students are examined in the classification according to the scientific creativity layers; students' awareness skill scores generally increased, observation skill scores decreased, strategy skill scores generally increased, whereas reflection skill scores increased in all students. When evaluated according to activities; it has been found that the strategy and reflection layers are mostly developed by the 6th final activity and it is determined that this activity is the most successful activity. When evaluated according to the scientific creativity total scores; of all students the score in the final activity were found to be higher than those in the score in the first activity. In addition, students have generally protected against each other in ranking of scientific 
creativity, but in the individual sense, scientific creativity performances have been developed throughout the process.

\section{Conclusions and Discussion}

In this research has been found that of the effect of STEM activities on students' scientific creativity was limited in terms of individual development and that in the "reflective thinking layer" which was the highest level of creativity, it was more effective. This finding is an important result for research because this layer of skill is regarded as the highest skill layer of scientific creativity. There are also studies in the literature that indicate that STEM education (Ceylan, 2014; Havice, 2015); STEAM education (Kim, Ko, Han and Hong 2014; Lee and Lee, 2013) and engineering applications (Samuels and Seymour, 2015; Suescun-Florez, Cain, Kapil and Iskander, 2013) have positive effects on students' scientific creativity. It has been determined that the scientific creativity scores of the students show fluctuations in the course of the process as increas and decreas. This is thought to be due to the fact that the activities and the related questions are becoming different and increasingly difficult. Time limitations of the research may also have prevented the full realization of the activities. Experimental studies should be carried out by using different activities related to STEM education and considering different variables. Since STEAM education emphasizes more creativity, STEAM researches should also be conducted to examine the development of scientific creativity. 